\title{
VARIANTNA INTONACIJA OSMEGA PSALMOVEGA TONA V KARTUZIJANSKI LITURGIČNI TRADICIJI
}

\author{
KATARINA ŠTER \\ Znanstvenoraziskovalni center SAZU
}

Izvleček: Dva kartuzijanska antifonarja iz 13. stoletja imata $v 8$. tonu posebno intonacijo $f$-a-cl namesto širše uveljavljene intonacije g-a-cl. Razprava poskuša osvetliti vprašanja: 1. Ali je intonacija $f-a-c 1 v 8$. tonu prisotna samo $v$ teh dveh ali pa vveč kartuzijanskih glasbenih rokopisih? 2. Ali so kartuzijanski glasbeni rokopisi pri uporabi omenjene intonacije povezani s kako drugo tradicijo? 3. Vkaterem času je bila intonacija f-a-cl v kartuzijanskih rokopisih najbolj razširjena?

Ključne besede: oficijska psalmodija, kartuzijanski glasbeni rokopisi, akvitanski glasbeni rokopisi

\begin{abstract}
Two Carthusian antiphoners from the 13th century contain a special intonation for the 8th psalm tone, with the notes Fa, La and Do (the Fa-intonation) instead of the more generally known intonation with the notes Sol, La and Do (the Sol-intonation). This paper discusses the following questions: 1. Can this special intonation of the 8th mode only be found in these two antiphoners, or also in other Carthusian music manuscripts? 2. Was the use of this intonation in the Carthusian music manuscripts connected with any other liturgical tradition? 3. In which period was the Fa-intonation most widely spread?
\end{abstract}

Key Words: office psalmody, Carthusian plainchant manuscripts, Aquitanian plainchant manuscripts

Srednjeveški liturgični rokopisi izkazujejo pripadnost različnim liturgičnim tradicijam, ki so si bile bolj ali manj različne. Ena od teh je bila kartuzijanska. Kartuzijani si sicer niso prizadevali, da bi bili samosvoji; bolj kot to so se navezovali na starejšo tradicijo, ki so jo jemali kot avtoriteto. Kljub temu pa so v kartuzijanskih liturgičnoglasbenih rokopisih posebnosti, ki jih v drugih rokopisnih izročilih ni. Med takšnimi posebnostmi je tudi intonacija 8. psalmovega tona v oficijski psalmodiji, kakršno vidimo v dveh kartuzijanskih antifonarjih iz 13. stoletja. To je intonacija f-a-c1, ${ }^{1} \mathrm{ki}$ se v teh dveh rokopisih pojavlja namesto bolj splošno razširjene intonacije g-a-cl² (gl. glasbeni primer 1).

1 V nadaljevanju: intonacija F. Izraz intonacija F se v tej razpravi uporablja izključno za intonacijo f-a-cl pri psalmih 8. tona.

2 V nadaljevanju: intonacija G. Izraz intonacija G se v tej razpravi uporablja izključno za intonacijo 
Čeprav se intonacija $\mathrm{F} v$ določenih kartuzijanskih rokopisih redno pojavlja in je avtorji, ki so se v zadnjem času ukvarjali s kartuzijanskimi glasbenimi rokopisi, skoraj nikoli ne pozabijo omeniti, ostajajo tovrstne omembe vedno le na ravni opažanja. Vzrok temu je najbrž to, da se glede na število odprtih vprašanj pri študiju rokopisov vprašanje enega samega tona ne zdi pomembno, še zlasti če izbira tona g ali f ne spreminja modalne pripadnosti psalmodičnega obrazca. Prav tako otežuje temeljito primerjavo med rokopisi dejstvo, da kartuzijanski glasbeni rokopisi - podobno kot večina rokopisov ostalih tradicij znotraj gregorijanskega korala - ne navajajo vedno intonacij psalmov in jih tako za številne rokopise sploh ni mogoče določiti. Kljub temu je z omembami teh intonacij včasih povezano neko nelagodje: pojav je opisan, saj ga je potrebno omeniti zaradi znanstvene doslednosti, ne vemo pa, kaj bi z njim, kako bi ga pojasnili, v katerem kontekstu oz. koliko je pomemben in koliko pozornosti bi mu sploh posvetili. Posamezne obsežnejše študije širšega izbora gregorijanskih rokopisov se pri obravnavi psalmovih tonov večinoma ukvarjajo samo z diferencami, intonacije pa običajno jemljejo za samoumevne ali pa za en psalmov ton navajajo samo eno možno intonacijo (za 8. ton običajno intonacijo G).

Pričujoča razprava ne bo mogla odpraviti tega nelagodja in v celoti pojasniti, kako in zakaj se v nekaterih kartuzijanskih rokopisih pojavlja za 8. psalmov ton intonacija F. Poskušala pa bo to vprašanje osvetliti in ponuditi nekaj domnev v zvezi z njo. Za boljše razumevanje intonacije $\mathrm{F}$ bi bilo potrebno poznavanje njenega celotnega konteksta, ki je mnogo širši od konteksta enega rokopisa ali dveh, morda celo širši od konteksta tistih kartuzijanskih rokopisov, ki jo poznajo. Članek želi na prvem mestu na to intonacijo opozoriti in pokazati nekaj smeri, v katere bi se raziskava lahko usmerila v nadaljnjih študijah.

\section{Glasbeni primer 1: intonaciji 8. psalmovega tona (intonacija F in intonacija G)}

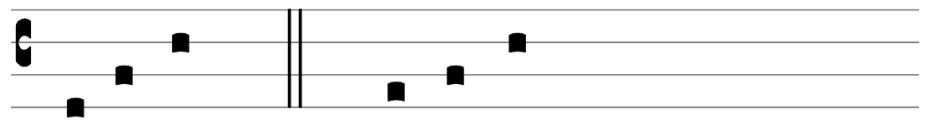

Petje psalma po določenem obrazcu (psalmovem tonu) je povezano s petjem antifone, ki se poje pred njim in za njim. Psalm in antifona se povezujeta tako po vsebini besedila kot po glasbenih značilnostih. Modus antifone, ki oklepa neki psalm, določata finalna nota in sama zgradba speva iz značilnih fraz, razviden pa je tudi iz psalmodičnega obrazca pripadajočega psalma. Ta je opredeljen predvsem z diferenco, ki je v rokopisih domala zmeraj navedena, in z recitacijskim tonom. ${ }^{3}$

g-a-cl pri psalmih 8. tona.

$3 \mathrm{~V}$ tej razpravi se izraz »psalmov ton « uporablja izključno za obrazce za petje psalmov, medtem ko je »modus« mišljen širše, kot neka bolj abstraktna lastnost tako psalmodičnih obrazcev kot drugih spevov. Razprava namreč obravnava vire iz časa, ko sta bila pojma že zelo povezana in prepletena med seboj. O kompleksnem razmerju med modusi in psalmovimi toni gl. Terence Bailey, Latin monophonic psalmody (6. The connection between psalm tone and mode), s. v. Psalm (§2), Grove Music Online (4. december 2009); prim. tudi Jurij Snoj, Gregorijanski koral, Ljubljana, Založba ZRC, ZRC SAZU, 1999, str. 112-114. 
Za določanje psalmovega tona in modusa celotnega speva intonacije niso tako pomembne; isto intonacijo imata lahko obrazca dveh različnih modusov (npr. 1. in 6. psalmov ton). Ravno zato, ker je bila intonacija v določeni liturgičnoglasbeni tradiciji v vsakem modusu običajno ena sama in je bila liturgičnim akterjem znana že na podlagi diference in modusa antifone, je bila tako rekoč samoumevna in v rokopisih pogosto tudi ni izpisana. Možnih diferenc je bilo v posameznih psalmovih tonih precej več (to je bilo najverjetneje povezano z različnimi možnimi začetki antifon v posameznih modusih) in zato so bile običajno izpisane, njihovo število pa se je prav tako razlikovalo glede na pripadnost posamezni tradiciji. ${ }^{4}$ Večina rokopisov - pa ne le kartuzijanskih, ki so v tem pogledu z informacijami razmeroma velikodušni - intonacij psalmov, od katerih je vsakemu modusu pripadala le ena in ki so bile v ustni tradiciji dobro znane, zato ne navaja. Tudi zato je preučevanje intonacij nekoliko problematično. V splošnem so njihovi zapisi $\mathrm{v}$ rokopisih prej izjema kot pravilo.

Kaj sploh je intonacija psalma? Intonacija ali inicij sodi med t. i. inflekcije oz. drobne tonske figure; inflekcija je »odmik od neke tonske višine ali tonskih višin, ki se na neki način pojmuje kot standard «. ${ }^{5} \mathrm{~V}$ glasbenih enciklopedijah je intonacija opredeljena kot tista figura, s katero se dvignemo na recitacijski ton (ali, v primeru 4. psalmovega tona, začetna figura ob recitacijskem tonu). Obrazci za oficijske psalme poleg intonacije poznajo še dva tipa inflekcij oz. takšnih figur: zaključno diferenco oz. terminacijo (ali finalis) ter vmesno medianto. ${ }^{6}$ Od vseh treh se najbolj pogosto in splošno uporablja zaključna kadenca (diferenca), intonacija pa je najhitreje opuščena. ${ }^{7}$ Nekatere tradicije intonacije sploh niso imele $^{8}$ ali pa so se ji odpovedale kasneje (npr. cistercijani). ${ }^{9}$ Sicer pa je koralna praksa celo za psalme dni med tednom predvidevala začetni inicij oz. intonacijo za prvi verz psalma. ${ }^{10}$

Če iščemo intonacijo F za obrazce 8. psalmovega tona, je v splošnih večjih monografijah in priročnikih o gregorijanskem koralu ne bomo našli. V poglavju o liturgičnem recitativu omenja W. Apel za 8. ton samo intonacijo G, ki je bila v srednjem veku in še kasneje očitno najbolj razširjena. ${ }^{11}$ Enako omenja samo to intonacijo tudi D. Hiley. ${ }^{12}$ Podobno navaja P. Wagner kot intonacijo 8. psalmovega tona intonacijo G, pri čemer se sklicuje na traktat Commemoratio brevis de tonis et psalmis modulandis iz 9. stoletja, pa tudi na nekaj glasbenih rokopisov. ${ }^{13} \mathrm{Ob}$ tabeli, ki prikazuje italijanske in francoske

4 Prim. J. Snoj, nav. delo, str. 115; Lila Diane Collamore, Aquitanian collections of Office chants: a comparative survey, Ann Arbor, University Microfilms International, 2000, str. 194 (Catholic University of America, ponatis disertacije).

5 Walter Howard Frere, Owen Jander in Peter Cooke, Inflection, Grove Music Online (22. september 2011).

6 W. H. Frere, O. Jander in P. Cooke, nav. delo; prim. tudi J. Snoj, nav. delo, str. 111-118.

7 W. H. Frere, O. Jander in P. Cooke, nav. delo.

8 Taka je bila npr. ambrozijanska. T. Bailey, nav. delo (5. The development of recitation formulae).

9 John A. Emerson, Jane Bellingham in David Hiley, Chant in the religious orders ((ii) Other orders, (b) Cistercians), s. v. Plainchant (§7), Grove Music Online (22. september 2011).

${ }^{10} \mathrm{~T}$. Bailey, nav. delo (5. The development of recitation formulae).

${ }^{11}$ Willi Apel, Gregorian Chant, Bloomington in Indiana, Indiana University Press, 1990, str. 227.

${ }^{12}$ Hiley navaja psalmove tone iz rokopisa Piacenza, Biblioteca capitolare 65 , fol. 264v-267v. David Hiley, Western plainchant, Oxford, Clarendon Press, 1993, str. 59-60.

${ }^{13}$ Peter Wagner, Einführung in die gregorianischen Melodien. Ein Handbuch der Choralwissenschaft 
psalmove tone, pa v opombi vendarle omeni, da ima eden od preučevanih rokopisov v intonaciji začetni ton $\mathrm{f}-$ da uporablja torej za 8. psalmov ton intonacijo F. Pojava te intonacije Wagner ne pojasnjuje posebej. ${ }^{14}$

Večje glasbene enciklopedije intonacije F za 8. psalmov ton ne navajajo. Med glavnimi recitacijskimi obrazci, ki jih za tone oficijske psalmodije navaja T. Bailey, se pojavlja samo standardna intonacija G. ${ }^{15}$ Osnovne psalmove tone je Bailey povzel po zgoraj omenjenem traktatu Commemoratio brevis. Prav tako navaja glavne tone iz istega traktata J. Dyer: tudi pri njem ima 8. ton intonacijo G. ${ }^{16}$

V zgoraj omenjenem enciklopedičnem članku je Bailey opozoril na to, da so vedno obstajale tudi razlike v melodičnih detajlih psalmovih tonov; največ jih je bilo sicer v številu diferenc, a tudi intonacije niso bile izjema. Čeprav so v visokem in poznem srednjem veku različne tradicije običajno poznale po eno intonacijo za vsak psalmov ton, je bila ta praksa v času prvih zapisov korala še dokaj neenotna; psalmi so imeli več intonacij in diferenc, kot se jih je ohranilo pozneje, ne nazadnje je obstajalo tudi več kot 8 psalmovih tonov (od t. i. parapteres tonov se je do danes ohranil le tonus peregrinus). Starejša praksa je bila bolj raznolika in manj sistematična; s težnjo po teoretski utemeljitvi in posledičnem poenotenju koralne glasbe je bilo opuščeno veliko intonacij in diferenc. Vendar se jih je nekaj vseeno ohranilo dlje časa; obstoj dveh enakovrednih intonacij za en psalmov ton je znan npr. iz traktata Commemoratio brevis, ki za vse psalmove tone - razen za 2., 4. in 7. - navaja po še eno intonacijo poleg najbolj splošno uveljavljene. ${ }^{17}$ Obstoj same intonacije F poleg intonacije $\mathrm{G}$ za 8. psalmov ton tako ne bi pomenil nič nenavadnega; lahko bi bila to ena od običajnih intonacij 8. psalmovega tona, ki se je ohranila iz neke starejše tradicije.

Intonacija $\mathrm{F}$ glede na svoj glasbeni potek v 8. modusu ne predstavlja posebnosti; figura tonov f-a-c1 ni namreč za 8. modus nič nenavadnega; je nekakšen okvir finalne note $\mathrm{g}$ in recitacijskega tona $\mathrm{cl}$, tako $\mathrm{v}$ psalmodičnih tonih kot $\mathrm{v}$ drugih spevih. Pogosto jo npr. najdemo na začetkih repetendumov in verzov v responzorijih; slednji dolgo časa niso bili notirani in so se verjetno peli kot nekakšna improvizacija na obrazce psalmovih tonov. ${ }^{18} \mathrm{Na}$ to opozarja tudi D. Saulnier, ki figuro opredeljuje kot $» k a r a k t e r i s t i c ̌ n o ~ p o t e z o$ 8. modusa«, ki pogosto označuje »reprizo melodije« v 8. modusu. Pri tem je ton f, ki je za intonacijo 8. modusa v tem kontekstu najbolj izstopajoč, za Saulnierja nekakšen močan »spodnji ornament tona g, ki kaj hitro postane pravi temelj in pogosto podpira pomembne notranje kadence $\ll$. Obenem Saulnier pravi, da je treba triado f-a-cl razlikovati od iste figure v 5. modusu, kjer je arhitekturnega pomena, medtem ko ima v 8. modusu, čeprav je tu močna in pogosta, bolj ornamentalno vlogo. ${ }^{19}$ Vendar se kljub Saulnierjevim opaža-

III, Leipzig, Breitkopf \& Härtel, 1921, str. 89-90 in 100-101.

${ }^{14}$ P. Wagner, nav. delo, str. 97.

15 T. Bailey, nav. delo (6. The connection between psalm tone and mode, 7. The simple psalm tones of antiphonal psalmody).

${ }^{16}$ Joseph Dyer, Lateinisch, einstimmig, s. v. Psalm, Die Musik in Geschichte und Gegenwart. Sachteil 7, Bärenreiter, Kassel [...], 1997, stolp. 1862-1876: 1865-1868.

${ }_{17} \mathrm{~T}$. Bailey, nav. delo (5. The simple psalm tones of antiphonal psalmody).

${ }^{18} \mathrm{~T}$. Bailey, nav. delo (6. The connection between psalm tone and mode).

${ }^{19}$ Dom Daniel Saulnier, The Gregorian Modes, prev. Edward Schaefer, Solesmes, Abbaye SaintPierre, 2002, str. 99-100. 
njem zdi, da ima ton $\mathrm{f}$ vendarle pomembno vlogo $\mathrm{v}$ arhitekturi 8. modusa in da njegova vloga ne more biti omejena zgolj na ornamentalnost. Že sam Saulnier v nadaljevanju tako navaja opažanje Jeana Jeanneteauja, ki meni, da ta figura bistveno prispeva k značilni trdni zvočnosti 8. modusa. Tona g in f sta pri tem močni bazi dveh bistvenih kvart 8 . modusa. ${ }^{20} \mathrm{Za}$ več kot ornamentalno pojmuje to figuro tudi M. Huglo, ki je v pismu Hj. Beckerju zapisal, da »kvinta, sestavljena iz dveh sklenjenih terčnih skokov [f-a in a-cl] ni tuja arhitekturi nekaterih spevov 8. modusa. ${ }^{21}$

Ker je intonacija f-a-cl za 8. psalmov ton ista kot intonacija 5. psalmovega tona, vedno obstaja tudi možnost, da gre za napačno pripisovanje modusu ali modalno ambivalenco določenega speva. Znani so nekateri spevi, ki jih nekatere tradicije pojmujejo kot pripadajoče 5., druge pa 8. modusu, kar je odvisno predvsem od finalisa antifone (taka je npr. antifona In sole posuit, ki je obravnavana v nadaljevanju). V tem primeru je lahko uporaba intonacije $\mathrm{F}$ ali diference 5. oz. 8. tona povezana tudi s pripisovanjem speva drugemu modusu. Takšni zanimivi primeri kažejo, kako blizu so si bili morda določeni spevi 5. in 8. modusa in kako malo se lahko razlikujejo spevi, ki so bili na podlagi istega ključa različno uvrščeni v modalni sistem..$^{22} \mathrm{Na}$ to dejstvo velja opozoriti, nas pa na tem mestu zanimajo predvsem intonacije psalmov antifon, ki se končajo na tonu g in so v 8. modusu, in sicer intonacije $\mathrm{F}-\mathrm{z}$ izjemo primerov napačne določitve modusa ali morebitnih napak (ko je npr. finalis antifone g, diferenca psalma pa kaže na 5. modus).

Izhodiščna vira pričujoče razprave, zaradi katerih je razprava pravzaprav nastala, sta dva kartuzijanska antifonarja iz 2. polovice 13. stoletja. ${ }^{23}$ To sta rokopis 273 iz Univerzitetne knjižnice v Gradcu (Universitätsbibliothek Graz, A-Gu, Hs. 273) ${ }^{24}$ ter rokopis 509 iz Mestne knjižnice v Lyonu (Bibliothèque municipale Lyon, F-Lym, Ms. 509). ${ }^{25}$ V osnovni in prvotni plasti rokopisa 273 najdemo kot značilno intonacijo oficijskih psalmov 8. modusa intonacijo F. Intonacija G se v prvotni plasti rokopisa 273 pojavi le redko, kljub temu pa je tu že prisotna (npr. na foliju 29v, vrstica 8; ta folij vsebuje v vrstici 10 tudi izvirno intonacijo F; gl. sliko 1). Podobno je z rokopisom 509, v katerem so bile prvotne intonacije F kasneje $v$ veliki meri korigirane $v$ intonacije $G$, tudi tu pa najdemo izvirne intonacije $\mathrm{G}$ (npr. na foliju 123v, vrstica 11). V prvem delu rokopisa 509 so bile korekture iz intonacije F v intonacijo G dosledno izvedene, v osrednjem delu pa je korektor postal nekoliko površen. Prvotne intonacije F so pogosto ohranjene pri psalmih, ob katerih so antifone

${ }^{20}$ D. Saulnier, nav. delo, str. 102.

${ }^{21}$ Pismo Michela Hugloja Hj. Beckerju z dne 3. marca 1973. Navedeno in prevedeno po delu: Hansjakob Becker, Das Tonale Guigos. Ein Beitrag zur Geschichte des liturgischen Gesanges und der Ars Musica im Mittelalter I, Münchener Beiträge zur Mediävistik und RenaissanceForschung 23, München, Arbeo-Gesellschaft, 1975, str. 147.

${ }^{22}$ Wagner omenja celo to, da imajo nekateri stari rokopisi v intonaciji 5. psalmovega tona namesto tona f ton $\mathrm{g}$ (večina jih ima sicer ton $\mathrm{f}$ ), tako da so morda tudi speve 5 . modusa včasih napačno tolmačili prav na podlagi tega dejstva. P. Wagner, nav. delo, str. 117.

${ }^{23}$ O njuni medsebojni primerjavi na ravni liturgične vsebine in nekaterih melodičnih značilnosti gl. Katarina Šter, Dva kartuzijanska antifonarja iz 13. stoletja in vprašanje enotnosti kartuzijanskega liturgičnoglasbenega izročila, De musica disserenda VII/1 (2011), str. 7-34.

${ }^{24} \mathrm{~V}$ nadaljevanju: rokopis 273.

${ }^{25} \mathrm{~V}$ nadaljevanju: rokopis 509. 
zapisane samo z incipiti in se s kazalkami sklicujejo na druga mesta $\mathrm{v}$ rokopisu (npr. na foliju 137r). Najbolj očiten dokaz korektur so mesta, kjer je korektor ton $\mathrm{f} v$ prvotnem zapisu intonacije izbrisal, potem pa je pozabil na njegovo mesto napisati ton $\mathrm{g}$ (na foliju 146v.3 je tako izbrisana kar cela intonacija), ali pa tista mesta, kjer je ton g že napisal, pozabil pa izbrisati ton $\mathrm{f}$ (npr. na foliju 212r.7). V drugem delu rokopisa 509 najdemo več prvotno zapisanih intonacij, korekture $\mathrm{v}$ intonacijo $\mathrm{G}$ so ponovno bolj pogoste na koncu.

Oba kartuzijanska rokopisa iz 13. stoletja kažeta nekaj temeljnih izhodišč: 8. psalmov ton ima tu dve intonaciji, od katerih je ena prevladujoča oz. normativna, druga pa redka, a očitno tudi znana. Razlike med tem, kdaj je uporabljena ena ali druga intonacija v izvirnem zapisu, ni mogoče ugotoviti ne glede na diferenco psalma ne glede na melodične značilnosti predhodne antifone. Najverjetneje gre za zavestno hoteno zapisovanje ene intonacije (intonacije F), v katerega se vmešava poznavanje druge (intonacije $G$ ) ali celo prepisovanje iz predloge $\mathrm{z}$ intonacijo $\mathrm{G}$. Intonacija $\mathrm{F} v$ primeru teh dveh rokopisov predstavlja pravilo, intonacija G pa nekakšno izjemo. Nadalje: omenjena intonacija F je bila vsaj v teh dveh rokopisih kartuzijanske tradicije časovno zamejena, saj so bile intonacije F za 8. psalmov ton kasneje (verjetno že v 14. stoletju) v obeh rokopisih korigirane $\mathrm{v}$ intonacije $\mathrm{G}$.

Na podlagi zapisov intonacij $F$ in $G$ se je mogoče vprašati tudi to, kakšna je bila izvajalska praksa v teh dveh samostanih. Oficij (sploh pa nočni oficij, pri katerem je bila razsvetljava zelo uborna) so kartuzijani peli na pamet; psalme so menihi dobro poznali, saj je učenje in memoriziranje psalmov sodilo med temeljne učne dolžnosti novicev. Za izvedbo v koru so verjetno uporabljali eno samo intonacijo, saj bi bilo pri petju na pamet brez zelo jasnega pravila glede uporabe intonacije $\mathrm{F}$ ali intonacije $\mathrm{G}$ (ki ga npr. v rokopisu 273 ni bilo mogoče odkriti ne glede na diferenco psalma ne glede na melodijo antifone) težko vedeti, katero intonacijo je treba izbrati. Resda je psalm intoniral en menih, vendar so se kartuzijani pri tej nalogi izmenjevali; vsakokratno izbiranje med dvema intonacijama bi pomenilo nekaj zmede in oklevanja pri tistem, ki bi ga ta naloga doletela. ${ }^{26}$ Če bi bila izbira intonacije poljubna, si verjetno tudi zapisi v rokopisih ne bi tako jasno prizadevali za eno ali drugo različico, še manj pa bi bilo prav tu toliko popravkov. To, da popravki nekje manjkajo, pa je po drugi strani mogoče razložiti prav s psalmodiranjem na pamet, brez knjige.

Na podlagi zapisov omenjene intonacije se je mogoče vprašati: Ali obstaja med zgoraj omenjenima rokopisoma kakšna posebna povezava ali pa je bila ta intonacija vezana na rokopise kartuzijanske tradicije na splošno? Jo najdemo samo v antifonarjih ali še v katerih drugih liturgičnoglasbenih knjigah reda? Ali se pojavlja samo v rokopisih, sočasnih rokopisoma 273 in 509, ali pa tudi v rokopisih, ki so zgodnejši ali kasnejši od njiju? Da bi dobili odgovore na ta vprašanja, je potrebno v primerjavo vključiti več kartuzijanskih rokopisov, ki bodo morda pojasnili tudi uporabo dveh intonacij (F in G) v istem rokopisu ter morebitno časovno zamejenost intonacije $\mathrm{F}$ za 8. psalmov ton.

Najbolj smiselno je začeti s primerjavo več kartuzijanskih rokopisov, ki bo pokazala,

${ }^{26}$ Za drugi verz je bila situacija lažja, saj so ga najverjetneje začenjali kar na tonu recitacije. Wagner navaja, da izpisuje kartuzijanski rokopis iz 12. stoletja, ki ga sam imenuje »Codex Rosenthal«, tudi drugi verz, in sicer brez inicija. P. Wagner, nav. delo, str. 115. 
Slika 1: Gradec, Univerzitetna knjižnica, rokopis 273 , fol. 29v (z dovoljenjem)

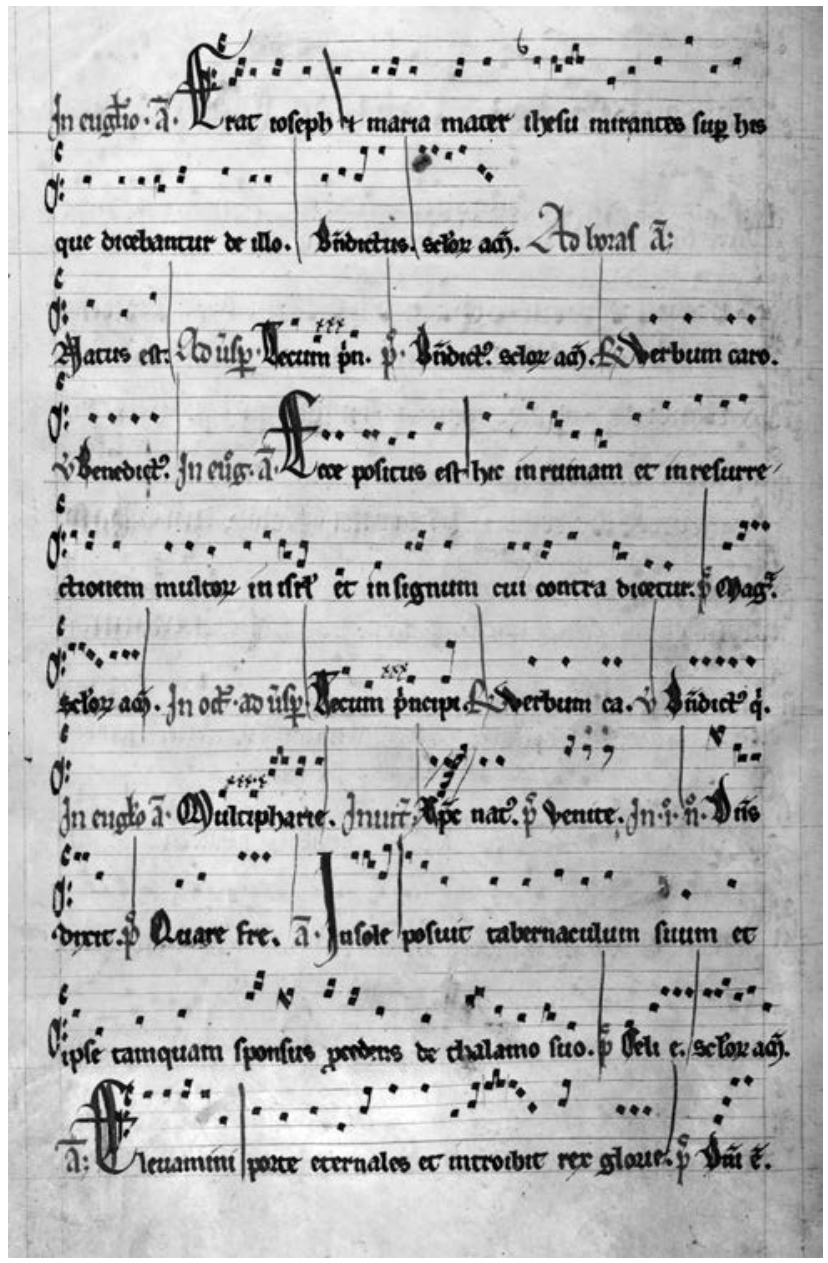

ali je poleg rokopisov 273 in 509 intonacija F prisotna še v katerem rokopisu. Če se to potrdi, je potrebno nadalje določiti, kako pogosta je intonacija $\mathrm{F}$ v okviru enega rokopisa ter kje in kdaj se pojavlja. Je bila lokalnega pomena in vezana le na nekatere kartuzijanske centre ali pa je bila širše poznana?

V primerjavo lahko najprej vključimo nekaj naključno izbranih kartuzijanskih rokopisov, tudi tistih, ki so jih različni avtorji že omenjali v zvezi z intonacijo 8. psalmovega tona. Intonacijo F oz. G, ki se pojavlja v oficijski psalmodiji kartuzijanov, bomo najlažje našli v antifonarjih. A. Devaux v kritični izdaji kartuzijanskega graduala omenja, da vsebuje intonacijo F neki kartuzijanski antifonar iz Kalabrije iz 12. stoletja. ${ }^{27}$

Hj. Becker omenja kartuzijanski antifonar iz 13. stoletja, ki se hrani v Mestni knjižnici

${ }^{27}$ Rokopis se hrani v knjižnici Vedana v Firencah. Točnejše signature Devaux ne navaja. Graduel cartusien 4 (Chant, Sanctoral), ur. Dom Augustin Devaux, Analecta cartusiana 228/4, Salzburg, Institut für Anglistik und Amerikanistik der Universität Salzburg, 2005, str. 785. 
v Grenoblu. ${ }^{28}$ Tudi ta skoraj brez izjeme uporablja intonacijo F; deloma je bila kasneje korigirana $\mathrm{v}$ intonacijo $\mathrm{G} .^{29}$

Med spletno dostopnimi rokopisi je kartuzijanski antifonar iz 14. stoletja, ki se prav tako hrani v Mestni knjižnici v Grenoblu. ${ }^{30} \mathrm{Na}$ spletno objavljenih straneh tega rokopisa intonacije F ni, najdemo pa sedem intonacij G za psalme 8. tona. Med temi so zagotovo vsaj tri izvirne, v štirih primerih pa iz dostopnega faksimila ni mogoče razbrati, ali gre za korekturo predhodne intonacije $\mathrm{F}$ ali za izvirno zapisano intonacijo G; okoli mesta tona $\mathrm{f}$ in tudi na sami spodnji črti f so vidne razure, tako da ni izključeno, da je bil prej na teh mestih zapisan ton $\mathrm{f}$, kar pomeni intonacija $\mathrm{F}$.

V grenobelski Mestni knjižnici je še en kartuzijanski antifonar, ki izhaja iz 15. stoletja. ${ }^{31} \mathrm{Na}$ dostopnih fotografijah so v rokopisu za večino psalmov izpisane le diference; tako je vedno vsaj v primeru 8. tona. Le za Magnificat in Benedictus navaja rokopis tudi intonacijo, in sicer intonacijo kantikov za 8. ton, ki pa je običajno, čeprav ne vedno drugačna od intonacije oficijskih psalmov 8. tona.

Medtem ko oba starejša antifonarja uporabljata intonacijo $\mathrm{F}$, tega za mlajša rokopisa iz Grenobla (14. in 15. stoletje) ni mogoče trditi. Tudi če domnevamo, da je prvi od teh dveh antifonarjev nekoč imel izvirno intonacijo F za 8. ton, tega ni mogoče z gotovostjo trditi; na podlagi dostopnih faksimilov prav tako ni mogoče vedeti, katere intonacije je imel za ta ton rokopis iz 15. stoletja. Vsekakor pa izvirni zapisi (in morebitni posegi) v grenobelskem rokopisu iz 14. stoletja nakazujejo, da je bila bolj pogosta izbira za intonacije tega obrazca v tem času intonacija G. To se približno ujema s časom, ko so bile v rokopisa 273 in 509 vnesene korekture, kar je bilo v 14. stoletju ali še kasneje.

V primerjavo lahko vključimo še mlajše srednjeveške žičke antifonarje, ki jih tako kot rokopis 273 hrani Univerzitetna knjižnica v Gradcu in naj bi vsi nastali v 15. stoletju. To so rokopisi, ki se hranijo pod signaturami 18, 21, 145, 51 in $7 .{ }^{32} \mathrm{Z}$ izjemo rokopisa 145 ti rokopisi za antifonami redno navajajo intonacije psalmov, vsi pa navajajo njihove diference. ${ }^{33}$ Če zanemarimo nekaj izjem, velja, da imajo za posamezne tone iste intonacije in iste diference. Glede intonacij se najbolj razlikujejo prav v pogledu intonacij $\mathrm{F}$ in $\mathrm{G}$.

Če vzamemo za primer oficij epifanije, imajo žički antifonarji 15. stoletja za 8. psalmov ton v njem skoraj vedno intonacijo G, medtem ko ima rokopis 273 intonacijo F. Intonacija $\mathrm{G}$ je nasploh značilna za vse žičke antifonarje 15. stoletja. Ker pa so ti rokopisi nastali verjetno kot prepisi rokopisa 273 , v katerem se starejša intonacija redno pojavlja,

${ }^{28}$ Grenoble, Bibliothèque municipale, 867 (91).

${ }^{29} \mathrm{Hj}$. Becker, nav. delo, str. 147-148.

${ }^{30}$ Grenoble, Bibliothèque municipale, 418 (93). Izbrane digitalne fotografije tega rokopisa so dostopne na spletni strani imenovane knjižnice: http://manuscrits-medievaux.bm-grenoble.fr (28. september 2011).

${ }^{31}$ Grenoble, Bibliothèque municipale, 19 (94). Izbrane digitalne fotografije tega rokopisa so dostopne na navedeni spletni strani (28. september 2011).

${ }^{32}$ A-Gu, Hs. 18, Hs. 21, Hs. 145, Hs. 51, Hs. 7, v nadaljevanju: rokopis 18, rokopis 21, rokopis 145, rokopis 51 in rokopis 7 .

${ }^{33}$ Za prikaz intonacij in diferenc rokopisa 273 prim. Katarina Šter, Poznosrednjeveška monastična recepcija liturgičnega koralnega enoglasja na primeru antifonarjev iz žičke kartuzije, Ljubljana 2010, priloga B: B1-B10 (Univerza v Ljubljani, Filozofska fakulteta, doktorska disertacija). 
bi v njih morda lahko naleteli tudi na kak naključni zapis intonacije $F$, torej na spodrsljaj pri zapisu intonacije G. Preliminarni pregled je pokazal, da je v rokopisu 18 res nekaj takšnih spodrsljajev z intonacijo F namesto sicer običajne intonacije G, npr. pri psalmu Exaltabo te (6. antifona 1. nokturna praznika Vnebohoda, 142v), psalmu Dominus regnavit in kantiku Benedicite (oba v oficiju praznika sv. Petra, 194r). Drugi rokopisi, ki vključujejo ta dva praznika (v rokopisu 51 je tu lacuna), imajo na teh mestih intonacijo G. Zanimivo pa je, da je v rokopisu 21 pri psalmu Exaltabo te $\mathrm{v}$ istem vnebohodnem oficiju intonacija $G$ verjetno korektura prvotne intonacije F. Morda je pojav intonacije $F$ na obeh navedenih mestih zgolj napaka ali pa je bila prepisana iz predloge, po kateri sta bila rokopisa 18 in 21 kompilirana (verjetnost takšnega spodrsljaja pri prepisovanju iz rokopisa $z$ večjim številom intonacij $F$ je večja).

Zaradi teh naključno najdenih primerov so bili sistematično pregledani še drugi obsežnejši segmenti žičkih antifonarjev 15. stoletja. Od 2. adventne nedelje do vključno praznika Nedolžnih otrok ima rokopis 18 kar nekajkrat intonacijo F, največkrat korigirano v intonacijo G (npr. pri drugi antifoni lavd na fol. 17r). Še bolj zanimiva so mesta, kjer je prostor za prvo noto prazen (npr. pri psalmu tretje antifone lavd na fol. 20v) in ki nakazujejo domnevo, da se je prav v času pisanja rokopisa 18 odločalo, kakšna naj bo zapisana melodija inicija 8. modusa $v$ žičkih antifonarjih. Malo je verjetno, da bi bil notator tako neizkušen ali neveden, da ne bi vedel, kaj napisati, če bi bila praksa trdno ustaljena, ali da bi na prvi ton tolikokrat pozabil; takšnih mest je preveč, da bi jih lahko razumeli kot napake. Nekatera od praznih mest, kjer bi morala stati prva nota, so kasneje zapolnili s punctumi na tonu $\mathrm{g}$, ki so $\mathrm{v}$ večini primerov razpoznavno drugačni kakor druge note, saj so napisani s svetlejšim črnilom (npr. tretja antifona lavd na fol. 18v). Domnevati je mogoče, da se je prav ob teh korekturah postopoma uveljavljala intonacija G.

Rokopis 18 se s stališča zapisovanja intonacij 8. psalmovega tona kaže kot prehodni rokopis, ki je nastal na podlagi precej starejšega rokopisa, morda prav rokopisa 273. Drugi rokopisi, ki vsebujejo intonacije (rokopis 145 ima skoraj vedno le diference), imajo namreč na teh mestih intonacijo G. Vendar pa je tudi v rokopisu 51 mesto, ki se dozdeva kot korektura intonacije $\mathrm{F} v$ intonacijo $\mathrm{G}$ (božična vigilija, peta antifona lavd, fol. 21r). Če korekturi v rokopisih 21 in 51 nista naključni, bi lahko tudi ta dva rokopisa povezali z rokopisom 18 in posredno z rokopisom 273, še zlasti če bi primerjava intonacij 8. psalmovega tona $\mathrm{v}$ drugih delih teh rokopisov pokazala podobna mesta.

Skupina obravnavanih žičkih antifonarjev iz 15. stoletja kaže, da je bila intonacija F tudi v okviru ene same - žičke - tradicije časovno zamejena in da je intonacija G v 14. ali najkasneje v 15. stoletju popolnoma zamenjala intonacijo F. Po drugi strani kaže, da je lahko tovrstna melodična posebnost zanesljiv kazalec morebitnih sorodnosti in povezav med rokopisi. Vsekakor bi bilo študij žičkih rokopisov zanimivo razširiti še na rokopise srednjeveških nemških kartuzijanskih provinc, ki so bile bolj povezane s kartuzijami na Slovenskem (tu sta mišljeni predvsem provinci Alemania inferior in Alemania superior).

Kaj pa drugi liturgičnoglasbeni rokopisi reda? Nekatere oficijske antifone in psalmodične obrazce bi lahko našli v psalterjih. Univerzitetna knjižnica v Gradcu hrani pod signaturo 
Hs. 556 deloma notirani psalter s himnarjem iz Žič, ki je nastal v 15. stoletju. ${ }^{34}$ Ta rokopis le redko navaja intonacije psalmov; psalmi so v njem prisotni večinoma le $\mathrm{z}$ besedilom, tedenskim antifonam pa je dodana samo diferenca. Rokopis vsebuje tudi nekaj verzetov $\mathrm{z}$ odpevi in kratke responzorije, ki so v antifonarjih iz istega obdobja večinoma izpisani le $\mathrm{z}$ incipiti.

Med redkimi zapisi intonacij psalmovih tonov, ki jih navaja rokopis 556, je tudi intonacija 8. tona, vendar je to intonacija za kantik Benedictus, ki se razlikuje od običajne intonacije psalma (fol. 89r po prvotni foliaciji, fol. 46r po novodobni foliaciji). Še enkrat se intonacija 8. tona pojavi na fol. 49v (novodobna foliacija), v različici g-a-c1 (intonacija G), vendar je ta zapis kasnejši dodatek, ki se po pisavi in notnem zapisu razlikuje od ostalega rokopisa. Drugače kot rokopis, ki je pisan v kvadratni notaciji, je ta intonacija v gotski notaciji. Na naslednjem foliju (50r) se roka, ki je vnesla intonacijo G, izkaže za roko korektorja, ki je del prvotnega zapisa melodije v kvadratni notaciji izbrisal in ga nadomestil z zapisom $v$ gotski notaciji. Intonacijo 8. psalmovega tona najdemo tudi pri antifonah nokturnov, a povsod je to intonacija $\mathrm{G}$.

Še en žički psalter s himnarjem je Ms 21 iz ljubljanske Narodne in univerzitetne knjižnice, ${ }^{35}$ ki je prav tako iz 15 . stoletja. Čeprav je ta rokopis, tako kot predhodno omenjeni, deloma notiran, ne navaja intonacij, temveč samo diference psalmov.

Mašni rokopisi sicer ne vsebujejo oficijskih sestavin, kljub temu pa je v kartuzijanskih gradualih mogoče najti nekaj zvrstno oficijskih antifon s pripadajočimi psalmodičnimi obrazci. Med temi je tudi antifona v 8. modusu Lumen ad revelationem gentium, ki je namenjena »sprejemu sveč« (»ad suscipiendos Cereos«) na praznik svečnice oz. Marijinega očiščevanja (2. februar). ${ }^{36}$ Antifonarji te antifone nimajo, saj je bil omenjeni obred povezan z mašo. Kritična izdaja kartuzijanskega graduala, ki upošteva najstarejše vire, jo navaja hkrati z obrazcem za kantik Nunc dimittis. ${ }^{37}$ Ta ima na tem mestu preprostejši obrazec (enak kot za psalme) z intonacijo F za 8. psalmov ton. ${ }^{38}$ A. Devaux k temu pripominja,

${ }^{34}$ A-Gu, Hs. 556, v nadaljevanju rokopis 556. Nataša Golob ga datira ok. 1430. Nataša Golob, Srednjeveški rokopisi iz Žičke kartuzije (1160-1560), Ljubljana, Narodna galerija, 2006, str. 125.

${ }^{35}$ SI-Ln, Ms 21.

${ }^{36}$ Graduale triplex antifono uvršča med antifone za procesijo na ta praznik. Graduale triplex, Abbaye Saint-Pierre, Solesmes, 1979 (ponatis 1998), str. 540. - Kartuzijani tega speva niso peli pri procesiji, saj kartuzijanska liturgija popolnoma zavrača vsakršne procesije, kot je zapisano že v Consuetudines: »et hoc sciendum quod in nulla solemnitate processionem facimus «. Amand Degand, Chartreux (Liturgie des), Dictionnaire d'archéologie chrétienne et de liturgie 3/1, ur. Fernand Cabrol in Henri Leclercq, Pariz, Librairie Letouzey et Ané, 1924, stolp. 1045-1071: 1050, op. 14, in stolp. 1066-1067.

${ }^{37}$ Kantike z obrazci preprostejše psalmodije najdemo tudi v rokopisu 273, ki ima tudi tu za 8. ton pogosto intonacijo F. Intonacija 8 . tona je za kantike sicer nekoliko bogatejša kot za oficijske psalme.

${ }^{38}$ Graduel cartusien 4, str. 786. Becker pojmuje intonacijo F kot nekaj, kar je lastno samo oficiju, saj naj bi se v mašni psalmodiji 8. psalmov ton vedno začenjal na tonu g. Takšne razlike med liturgijo maše in oficija naj bi podpirale tudi njegovo domnevo o različnih izvorih kartuzijanskega antifonarja in graduala. Kartuzijanski antifonar naj bi bil kanoničnega izvora, s čimer pa se kartuzijanski avtorji (predvsem Lambres) ne strinjajo. Hj. Becker, nav. delo, str. 148-153. 
da imajo za to antifono intonacijo F skoraj vsi najstarejši rokopisi gradualov, ki so bili upoštevani pri kritični izdaji. ${ }^{39}$ Za primer navaja kar deset starejših kartuzijanskih gradualov, ki imajo to intonacijo, medtem ko ima šest drugih rokopisov (in druga roka v enem rokopisu s siceršnjo intonacijo F) intonacijo G. Zanimivo je, da je intonacija $\mathrm{F}$ prisotna $\mathrm{v}$ kartuzijanskih gradualih 12. stoletja (5 rokopisov), medtem ko v tem času intonacije G ni mogoče zaslediti. Rokopisi iz 12. stoletja so iz kartuzij Montrieux, Portes, Les Écouges, domnevno iz kartuzije Seillon ter iz neznane kartuzije. ${ }^{40} \mathrm{~V} 13$. stoletju najdemo obe intonaciji: trije od petih rokopisov imajo intonacijo F, dva pa intonacijo G. Rokopisi z intonacijo F prihajajo iz kartuzij Durbon in Portes, rokopisa z intonacijo G pa iz kartuzij Le Liget in Le Reposoir. ${ }^{41}$ Intonacija F je v 14. stoletju še prisotna, vendar le v dveh rokopisih; v tem času že prevladuje intonacija $\mathrm{G}$ (štirje rokopisi). Intonacija $\mathrm{F}$ je prisotna v rokopisih iz Toskane in Pariza, ${ }^{42}$ intonacija $G$ pa v rokopisih iz Toskane, Regensburga, Brugesa in Gorgone. ${ }^{43}$ V Parizu natisnjeni kartuzijanski gradual iz leta 1578 ima samo intonacijo G. ${ }^{44}$

P. Wagner navaja še en kartuzijanski gradual, v katerem je zasledil intonacijo F; to je že omenjeni »Codex Rosenthal«. Rokopis je nastal v 12. stoletju in je notiran v severnoitalski punktualni notaciji (»in norditalischer Punktschrift«) na štirih črtah. ${ }^{45}$ Psalmodični obrazci, vzeti iz tega rokopisa, so v Wagnerjevem delu navedeni ob psalmu Laudate dominum, in tako tudi obrazec 8 . modusa z intonacijo F. Pri tem ni jasno, ali je iz rokopisa vzet samo obrazec ali pa nastopa ta $\mathrm{v}$ njem prav ob navedenem psalmu. Tudi pogostnost intonacije $\mathrm{F} v$ obravnavanem rokopisu iz Wagnerjevega razpravljanja ni razvidna. ${ }^{46}$

A. Devaux je za svojo kritično izdajo upošteval predvsem zahodnoevropske kartuzijanske graduale, ne pa tudi graduala iz Bistre, ${ }^{47}$ čeprav sodi med starejše kartuzijanske liturgičnoglasbene vire tudi ta, za naš prostor pomemben vir. Bistrški gradual, ki izvira iz 13. stoletja, vsebuje tudi antifono Lumen ad revelationem gentium (fol. 23v), ob kateri pa navaja obrazec $\mathrm{z}$ intonacijo $\mathrm{G}{ }^{48}$

${ }^{39}$ Graduel cartusien 4, str. 785, op. 4.

${ }^{40}$ A. Devaux navaja naslednje signature: Sélignac 23 (Montrieux), Parkminster DD 10, prej A 33 (Portes), Grenoble 395, prej 84 (Les Écouges), Milano, Ambrosiana 70 (domnevno kartuzija Seillon), Grande Chartreuse, nekdanja signatura 801 (izvor neznan). Augustin Devaux, Introduction à l'Édition critique du Graudel cartusien, Graduel cartusien, Analecta cartusiana 228, Salzburg, Institut für Anglistik und Amerikanistik der Universität Salzburg, 2005, str. 1-52: 1.

${ }^{41}$ A. Devaux navaja naslednje signature: London, British Library, Add. 17303, Avignon 181 (oba iz kartuzije Durbon), Grande Chartreuse, nekdaj Portes 44 (Portes), Loches 16 (Le Liget), London, British Library, Add. 31384 (Le Reposoir). A. Devaux, nav. delo, str. 1.

${ }^{42}$ A. Devaux navaja naslednje signature: rokopis Vedana (nekdaj Firence), prva roka (iz Toskane), Bordeaux 102 (Pariz). A. Devaux, nav. delo, str. 1.

${ }^{43}$ A. Devaux navaja naslednje signature: rokopis Vedana (nekdaj Firence), druga roka (iz Toskane), München, Clm 12101 (Regensburg), Douai 132 (Bruges), Grande Chartreuse, nekdanja signatura 825-826 (Gorgona). A. Devaux, nav. delo, str. 1.

${ }^{44}$ Graduel cartusien, str. 785, op. 4.

${ }^{45}$ Peter Wagner, Einführung in die gregorianischen Melodien. Ein Handbuch der Choralwissenschaft II, Leipzig, Breitkopf \& Härtel, 1912, str. 129 (druga izdaja).

${ }^{46}$ P. Wagner, Einführung in die gregorianischen Melodien III, str. 97.

${ }^{47}$ NUK, Ms 22 (SI-Ln, Ms 22).

${ }^{48} \mathrm{O}$ njem sta pisala Janez Höfler, Starejša gregorijanika v ljubljanskih knjižnicah in arhivih, 
Še en kartuzijanski gradual se je ohranil z današnjega slovenskega ozemlja, in sicer žički, ki izvira iz 15. stoletja in se hrani v Univerzitetni knjižnici v Gradcu. ${ }^{49}$ Tudi ta vsebuje na fol. $184 \mathrm{v}$ omenjeno antifono, ki ima prav tako izpisan psalmodični obrazec $\mathrm{z}$ intonacijo G. Zapis te intonacije se zdi izviren, čeprav je ton $\mathrm{g} v$ drugem verzu izpisan z nekoliko temnejšim črnilom. Težko je presoditi, ali je to drugo črnilo ali pa je bila na tem mestu uporabljena le nekoliko večja količina črnila. ${ }^{50}$

Intonacija $\mathrm{F}$ je prisotna tudi v fragmentu tonarja, ki je priključen kartuzijanskemu gradualu, rokopisu Parkminster DD 10 (prej A 33). ${ }^{51} \mathrm{Hj}$. Becker se je spraševal, ali gre tu v resnici za kartuzijansko tradicijo Velike kartuzije ali za neko posebno nekartuzijansko tradicijo, povezano s kartuzijo Portes, kar naj bi predstavljalo odklon od tradicije Velike kartuzije. ${ }^{52}$ Fragment tonarja namreč ni nujno kartuzijanski, saj ni prvotni del graduala, pač pa mu je bil priključen. ${ }^{53} \mathrm{M}$. Huglo je ugotovil, da ima ta tonar iste speve in podobno razporeditev kakor kartuzijanski tonar iz Mestne knjižnice v Grenoblu, rokopis 124. Po njegovem je torej tonar iz Parkminstra verjetno kartuzijanski tonar, ki pa je nastal pred liturgičnim poenotenjem reda. ${ }^{54} \mathrm{M}$. Huglo nadalje ugotavlja, da so bili takšni tonarji v teku postopne in diskretne reforme nadomeščeni z drugimi, nekoliko preprostejšimi. Izdelava kartuzijanskih rokopisov »po eksemplarju « naj bi se pravzaprav začela po letu $1259 .{ }^{55}$ Če je ta domneva pravilna, bi bila vsekakor lahko povezana s postopnim izginjanjem intonacije F iz kartuzijanskih liturgičnih knjig od konca 13. stoletja dalje. Postopnost izginjanja je razložljiva s tem, da so nove liturgične knjige nastajale razmeroma počasi in da so se prav tako počasi uveljavljale spremembe $\mathrm{v}$ tradiciji, $\mathrm{v}$ kateri je liturgično petje potekalo večinoma na pamet.

E. de Coussemaker je pod splošnim naslovom Cujusdam carthusiensis monachi tractatus de musica plana ${ }^{56}$ izdal neki domnevno kartuzijanski tonar s podnaslovom Ars intonandi secundum regulas ab institutoribus Musicae traditas, ki ga je povzel po rokopisu

Kronika XIII (1965), str. 164-181: 164 in 176-180, in Jurij Snoj, Italian Influences in the Medieval Plainchant Manuscripts from Slovenia, Srednjevjekovne glazbene kulture na istočnoj i zapadnoj obali Jadrana do početka 15. stoljeća / Mediaeval Music Cultures on the Eastern and Western Shores of the Adriatic until the Beginning of the 15th Century, Radovi s međunarodnog muzikološkog skupa održanog u Splitu, Hrvatska, 21.-24. 05. 1997, Muzikološki zbornici 8, ur. Stanislav Tuksar, Zagreb, Hrvatsko Muzikološko društvo, 2000, str. 275-284: 276-277 in 282.

${ }^{49}$ A-Gu, Hs. 376. N. Golob datira dva dela rokopisa v leti 1451 in 1454. N. Golob, nav. delo, str. 126. Rokopis je dostopen na spletni strani Univerzitetne knjižnice v Gradcu, Sondersammlungen, Handschriften digital, http://ub.uni-graz.at/ (13. oktober 2011).

${ }^{50} \mathrm{Za}$ razliko od psalmov se $\mathrm{v}$ kantiku Nunc dimittis drugi verz ponovno začenja z intonacijo in ne $\mathrm{z}$ recitacijskim tonom. Tako je tudi pri drugih kantikih.

${ }^{51}$ Graduel cartusien 4, str. 785, op. 4; Hj. Becker, nav. delo, str. 147-148.

${ }^{52} \mathrm{Hj}$. Becker, nav. delo, str. 113.

${ }^{53} \mathrm{Hj}$. Becker, nav. delo, str. 149.

${ }^{54}$ Michel Huglo, Les tonaires: Inventaire, Analyse, Comparaison, Paris, Société française de musicologie, 1971, str. 354.

${ }_{55}$ M. Huglo, nav. delo, str. 355.

${ }^{56}$ Scriptorum de musica medii aevi novam seriem a Gerbertiana alteram [...], ur. Edmond de Coussemaker, Hildesheim, Georg Olms Verlagsbuchhandlung, 1963, str. 434-483 (reprografski ponatis izdaje Pariz 1867). 
iz Saint-Bavona, kopiranem v letih $1503-1504 .{ }^{57}$ V njem najdemo intonacijo G. ${ }^{58}$ Vendar pa ta tonar ni prepričljivo povezan s predhodnim traktatom in ne kaže kartuzijanskih značilnosti. Njegov kartuzijanski izvor je vprašljiv. ${ }^{59}$

Poleg liturgičnoglasbenih knjig in tonarjev so lahko pomemben vir za poznavanje intonacije F v kartuzijanski tradiciji glasbenoteoretski traktati. Sloviti glasbeni teoretik Heinrich Eger iz Kalkarja (1328-1408) je po študiju in predavateljski dejavnosti leta 1365 stopil v kartuzijanski red in velja za najpomembnejšega kartuzijanskega teoretika ${ }^{60} \mathrm{~V}$ svojem traktatu Cantuagium iz leta 1380 je pisal tudi o vprašanju modusov in psalmovih tonov. Cantuagium ima šest poglavij; peto in najobsežnejše poglavje obravnava cerkvene tone (moduse), njihovo razdelitev na avtentične in plagalne, njihove značilnosti (modalni etos), finalne tone in njihovo vlogo pri določanju modusa, začetke spevov, ambitus, tenorske tone, diference in značilnosti psalmodije $\mathrm{v}$ povezavi s posameznimi modusi. Eger na kratko omenja tudi intonacije, in čeprav priznava, da je njihova raba v različnih cerkvah nadvse raznolika, kot intonacijo 8. psalmovega tona navede tisto, ki se začne kvarto pod tenorskim tonom oz. tonom recitacije. Recitacijski ton 8. modusa je c, zato je jasno, da ima Eger v mislih intonacijo G. ${ }^{61}$ Cantuagium je nastal 15 let po Egerjevem vstopu v kartuzijanski red. Nekateri menijo, da naj bi bil napisan prav v glasbeni pouk sobratom kartuzijanom, ${ }^{62}$ zato smemo domnevati, da je bila intonacija, ki jo je Heinrich Eger poznal kot kartuzijansko intonacijo 8. psalmovega tona, intonacija G. To ponovno potrjuje domnevo, da je bila intonacija F konec 14. stoletja že zelo malo poznana; morda je bila v nemških kartuzijanskih provincah še manj razširjena kot drugje.

Intonacija F se ne kaže kot posebnost rokopisov 273 in 509, zato ne more biti argument o njuni neposredni povezanosti. Zdi se, da je bila značilna za vse vrste kartuzijanskih liturgičnih rokopisov 12. in 13. stoletja, čeprav ni bila nujno prisotna prav v vseh. V 14. stoletju je postopoma prešla iz rabe; izpodrinila jo je z drugimi tradicijami bolj usklajena intonacija G. Ker je bila intonacija F v kartuzijanskih glasbenih rokopisih časovno zamejena (od 14. stoletja dalje je redka, v 15. stoletju skoraj popolnoma izgine), je ob upoštevanju drugih značilnosti lahko splošni kazalec starosti danega kartuzijanskega rokopisa. Na časovno zamejenost te intonacije je opozoril tudi M. Huglo: »Intonacija F-a-c za 8. ton

${ }^{57}$ Nav. delo, str. 450-460.

${ }^{58}$ Nav. delo, str. 459.

${ }^{59}$ M. Huglo, nav. delo, str. 357.

${ }^{60}$ Karlheinz Schlager, Ars cantandi - ars componendi, Geschichte der Musiktheorie IV, Die Lehre vom einstimmigen liturgischen Gesang, ur. Thomas Ertelt in Frieder Zaminer, Darmstadt, Wissenscahftliche Buchgesellschaft, 2000, str. 217-292: 273-279.

${ }^{61} \gg$ Inchoationes etiam psalmodiarum apud diversas ecclesias diversimodae sunt; conveniunt tamen communiter puto in hoc, quod in solo quinto tono inchoatio fit a quinta sub chorda sua tonali, in secundo vero, tertio et octavo a quarta, in primo et sexto a tertia sub tonali. Quartum autem quidam inchoant a quarta sub tonali, quidam ab ipsamet tonali, septimum quidam a tertia sub tonali, quidam vero a proxima sub eadem.« Heinrich Eger von Kalkar, Cantuagium, ur. Heinrich Hüschen, Beiträge zur rheinischen Musikgeschichte 2, Köln, Staufen, 1952. Delo je dostopno na spletni strani Centra za zgodovino glasbene teorije in literature, Indiana University, http:// www.chmtl.indiana.edu (7. november 2011).

${ }^{62}$ Karl Loo, Select List of Late Medieval Treatises on Music, spletna stran Nota Quadrata, http:// www.notaquadrata.ca (7. november 2011). 
(namesto G-a-c) je izjemna različica, ki jo je treba razlagati bolj z obdobjem kot s krajem. Večina francoskih tonarjev [...] za začetek intonacije uporablja ton G. « ${ }^{63}$

Vendar bi bila intonacija F lahko tudi krajevno zamejena. P. Wagner (glej zgoraj) jo omenja v sklopu psalmodičnih obrazcev italijanskih in francoskih rokopisov, značilno pa je tudi to, da navajata tako A. Devaux kot Hj. Becker za to intonacijo samo francoske, italijanske in angleške rokopise. Deloma je to zato, ker so jima bili ti rokopisi laže dostopni, po drugi strani pa se je v Franciji in Italiji ohranilo večje število zgodnjih kartuzijanskih virov. V nemških provincah je mnogo kartuzij nastalo šele potem, ko se je proces menjave intonacije iz F v G že končal. Kljub temu bi vključitev virov nemških provinc nedvomno dodatno osvetlila zgodovino intonacije F.

Kot je pokazala primerjava med žičkimi antifonarji 15. stoletja na eni, in tistim iz 13. stoletja na drugi strani, je lahko intonacija F kot melodična posebnost zanesljiv kazalec in celo bistveni kriterij pri ugotavljanju morebitnih sorodnosti in povezav med rokopisi. V primeru kartuzije Žiče ni mogoče govoriti o lokalni zamejenosti intonacije F, saj je bilo za žičke antifonarje 15. stoletja bolj kot kraj nastanka odločilno to, po katerem rokopisu so bili kopirani. V takšnih primerih velja bolj kot o krajevni zamejenosti govoriti o zamejenosti na podlagi tradicije.

$\mathrm{Na}$ vprašanje, ali so kartuzijani v začetkih reda uporabljali samo eno intonacijo (F) ali dve ( $F$ in $G)$, ni mogoče jasno odgovoriti. Glede na to, da njihova liturgična praksa v začetku ni bila enotna, se zdi obstoj dveh intonacij za 8. psalmov ton že od začetka povsem verjeten. Morda sta ti dve intonaciji prav tako kot nekatere druge značilnosti kartuzijanskih melodij povezani s tradicijama dveh pomembnih kartuzij: Velike kartuzije in kartuzije Portes. O nekaterih razlikah med njima je razpravljal predvsem A. Devaux, ki je na podlagi različnih variant istih melodij nekaterih spevov v kartuzijanskih rokopisih izpeljal teorijo o »dvojni [melodični] tradiciji« in najmanj dveh melodičnih družinah kartuzijanskih gradualov ${ }^{64}$ in antifonarjev. Prva je melodična družina Velike kartuzije, druga pa je melodična družina kartuzije Portes, ki je z ustanovitvenim letom 1115 ena najstarejših kartuzijanskih ustanov sploh in se je v določenih obdobjih svoje zgodovine z Veliko kartuzijo potegovala za vpliv v redu. ${ }^{65}$ Koliko je ta dvojna melodična tradicija povezana $\mathrm{z}$ intonacijama $\mathrm{F}$ in $\mathrm{G}$, ostaja odprto.

Za natančno določitev povezav med rokopisi in presojo, v kolikšni meri je intonacija F pomembna značilnost kartuzijanske liturgične glasbe v posameznih obdobjih, bi bilo potrebno pregledati vse znane kartuzijanske liturgičnoglasbene rokopise iz različnih časovnih obdobij in različnih kartuzijanskih provinc. Vendar je že iz prikazanih primerjav razvidno, da je intonacija $F$ značilna za veliko število rokopisov starejše kartuzijanske rokopisne tradicije.

${ }^{63}$ Pismo Michela Hugloja Hansjakobu Beckerju z dne 3. marca 1973. Huglo v svojem delu Tonaires intonacije F sicer ne omenja. Navedeno in prevedeno po Hj. Becker, nav. delo, str. 147-148.

${ }^{64}$ Dysmas de Lassus, Études complementaires, Graduel cartusien, Analecta cartusiana 228, Salzburg, Institut für Anglistik und Amerikanistik der Universität Salzburg, 2005, str. 53-106: 53, 68-69, 80-81 idr.

${ }^{65}$ Augustin Devaux, Introduction à une édition critique de l'antiphonaire cartusien, Sélignac, 2000, str. 3-20: 10-12 (neobjavljeno; zahvaljujem se gospodu Gabrielu van Dijcku, ki mi je posredoval kopijo Devauxovega besedila). 
Intonacija F je v določenem času predstavljala značilno potezo kartuzijanske liturgičnoglasbene tradicije. Čeprav ni povsem nemogoče, je vsekakor malo verjetno, da bi nastala v kartuzijanskem redu, tj. da bi bila izvorno kartuzijanska. Kartuzijani so se močno navezovali na tradicijo in so že v začetku z nekaj spremembami prevzeli glasbeno tradicijo okolja, v katerem je red nastal. Pri prevzemanju spevov so posegali predvsem v njihova besedila, manj pa v njihove glasbene značilnosti, ${ }^{66}$ intonacij domnevno niso spreminjali in prav tako malo verjetno je, da bi kasneje uveljavili popolnoma novo in drugim tradicijam neznano intonacijo za 8. psalmov ton, saj so veljali za red, ki je prvotne melodije ohranil skoraj nedotaknjene. ${ }^{67}$ Najverjetneje je, da so kartuzijani (oz. določeni kartuzijanski viri) intonacijo F prevzeli iz neke druge tradicije, in sicer že zelo zgodaj, morda že v času prvih kartuzijanov, ki so - kot sta dokazala B. Lambres in A. Degand - oficij peli že od vsega začetka reda. ${ }^{68}$ Vzporedno z intonacijo F so morda prevzeli tudi intonacijo G; morda je temu botrovalo samo prepisovanje iz drugih, še ne raziskanih virov, ki najbrž niso bili povsem enotni. Pri preučevanju izvora kartuzijanskih liturgičnoglasbenih knjig se je večina študij osredotočala predvsem na besedila spevov, vseskozi pa so posamezni avtorji opozarjali, da bi raziskava melodij, ki še niso bile sistematično raziskane, morda privedla do drugačnih zaključkov. ${ }^{69}$ Raziskave besedil in nekaterih melodičnih detajlov kažejo, da je kartuzijanski koral izšel (tudi) iz akvitanske tradicije. ${ }^{70}$ Tako naj bi bili z njo usklajeni tudi psalmodični obrazci kartuzijanskih glasbenih rokopisov. ${ }^{71} \mathrm{O}$ akvitanskih vplivih na kartuzijanske rokopise je med drugimi razpravljal tudi M. Huglo, ki je opazil, da so nekateri najstarejši kartuzijanski rokopisi akvitanski, le da so korigirani v skladu z glasbenimi različicami kartuzijanskega reda. ${ }^{72}$

Nadaljnje preučevanje intonacije F v kartuzijanskih rokopisih se mora zato usmeriti v njihovo primerjavo z morebitnimi sorodnimi akvitanskimi glasbenimi rokopisi, predvsem antifonarji, ki vključujejo največ preproste oficijske psalmodije. V sledečo primerjavo so bili vključeni nekateri glasbeni primeri iz akvitanskih antifonarjev do 14. stoletja. ${ }^{73} \mathrm{~V} 14$.

${ }^{66}$ B. Lambres piše, da so pri kompiliranju kartuzijanskega antifonarja (iz drugih tradicij prevzete) melodije ostale največkrat nedotaknjene in običajno jih tudi niso krajšali. Benoît Lambres, Le chant des chartreux, Revue belge de Musicologie / Belgisch Tijdschrift voor Muziekwetenschap 24/1 (1970), str. 17-41: 24.

${ }^{67}$ A. Degand, nav. delo, stolp. 1067.

${ }^{68}$ Augustin Devaux, Les origines du missel des chartreux, Analecta cartusiana 99/32, Salzburg, Institut für Anglistik und Amerikanistik der Universität Salzburg, 1995, str. 39.

${ }^{69}$ Benoît Lambres, L'antiphonaire des chartreux, Études grégoriennes XIV (1973), str. 213-218: 217-218.

${ }^{70}$ A. Devaux, nav. delo, str. 41.

${ }^{71}$ B. Lambres, Le chant des chartreux, str. 29.

${ }^{72}$ M. Huglo, Tonaires, str. 352. Huglo tudi meni, da je liturgična enotnost v redu nastopila dolgo po ustanovitvi reda (1084), verjetno šele po prvem generalnem kapitlju, ki je to enotnost zapovedoval (1140). Generalni kapitelj najbrž ne bi posebej zapovedoval liturgične enotnosti, če bi ta v redu že obstajala. Verjetno se je v redu dokončno utrdila šele v času ok. leta 1259.

${ }^{73}$ Ti primeri so povzeti po L. Collamore, nav. delo. Rokopisi so v nadaljevanju označeni z istimi kraticami kot v delu L. Collamore: Huesca 2: Huesca, Archivo de la Catedral, 2; Huesca 7: Huesca, Archivo de la Catedral, 7; MB: Mdina [Malta], Cathedral Museum, B; P9: Paris, Bibliothèque nationale, lat. 1090; S9: Silos, Archivo del Monasterio benedictino de Santo Domingo, 9; T1: Toledo, Biblioteca capitolare, 44.1; T2: Toledo, Biblioteca capitolare, 44.2. 
stoletju je bila namreč srednjeveška kartuzijanska liturgija že stabilizirana in se ni več opirala na nobeno zunanjo tradicijo.

Intonacije so v akvitanskih antifonarjih le redko navedene, saj nekateri med njimi ne navajajo niti diferenc. V skupinah rokopisov (največkrat okoli osem), ki jih je v vzporedno primerjavo vključila L. Collamore, ima intonacije običajno le eden ali dva, in za 8. modus se tu včasih pojavlja tudi intonacija F. Med akvitanskimi rokopisi, ki navajajo to intonacijo, je Silos 9 (S9), ${ }^{74}$ v katerem nastopa intonacija F v vseh primerih psalmodije 8. modusa. Med drugim navaja intonacijo F tudi pri psalmih naslednjih antifon 8 . modusa: Novit dominus, Dixit dominus mulieri ${ }^{75}$ In sole posuit ter Generatio haec prava / mala ${ }^{76}$

$\mathrm{O}$ akvitanskih tonarjih M. Huglo ugotavlja, da se razlikujejo od severnofrancoskih le po nekaterih »melodičnih različicah v intonacijskih formulah«, sicer pa so jim zelo podobni. ${ }^{77}$ Verjetno so tu mišljene začetne fraze antifon, ne pa intonacije psalmovih tonov.

V zvezi z intonacijo F v akvitanskih rokopisih je mogoče zaslediti še en pojav. Znotraj te tradicije je zanimiv obstoj melodij, ki so modalno ambivalentne oz. se pripisujejo različnim modusom. Možnosti za različno pripisovanje modusom ni veliko; ambivalentnost je pogosta pri melodijah, ki so si podobne, čeprav pripadajo različnim modusom ipd. Primer slednjega so melodije, ki se pripisujejo 5. ali 8. modusu. Med njimi je npr. antifona Generatio haec, ki se v nekaterih akvitanskih antifonarjih zaključi s punctumom na tonu g, v drugih s punctumom na tonu f, v nekaterih pa s clivisom gf. $^{78}$ Minimalna razlika v zaključku privede do drugačnega finalisa in s tem drugačnega tolmačenja modusa celotne antifone, ki ima sicer povsod isto melodijo. S tem je povezano različno tolmačenje psalmovega tona, tj. uporaba drugega psalmovega tona.

Še bolj ambivalenten je primer antifone In sole posuit, ki se v nekaterih akvitanskih rokopisih konča na tonu f (5. modus), v nekaterih na tonu g (8. modus), medtem ko je v enem rokopisu finalis antifone sicer nečitljiv, diferenca pa nakazuje na 5. ton. V akvitanskih rokopisih je za to antifono 5. modus bolj običajen; v tem modusu se običajno pojavlja tudi v francoskih, italijanskih in angleških virih, medtem ko prevladuje v nemških virih 8. modus. $^{79}$ Zanimivo je, da je bil zaključek antifone In sole posuit $\mathrm{v}$ dveh rokopisih

${ }^{74}$ Rokopis Silos 9 je monastični antifonar s psalterjem in lekcionarjem iz opatije San Salvador de Celanova. Nastal je v 12. stoletju (po letu 1170) in obsega 396 folijev velikosti 268 x $182 \mathrm{~mm}$. Ima dve večji vrzeli. Notiran je v akvitanski notaciji na rdeči črti, ima pa tudi pet marijanskih antifon v kvadratni notaciji. Collamore ga skupaj z rokopisi T1, T2, Huesca 2 in Huesca 7 uvršča v ibersko skupino akvitanskih rokopisov. Ta skupina ima veliko skupnih glasbenih značilnosti in skupni repertoar, čeprav so rokopisi te skupine mestoma zelo podobni ostalim rokopisom akvitanske tradicije. Silos 9 se od te skupine mestoma nekoliko loči, saj večkrat sledi francoskim virom oz. provansalski skupini. L. Collamore, nav. delo, str. 280 in 633.

${ }^{75}$ Rokopis P9 navaja tu intonacijo G, ima pa isto diferenco kakor rokopis S9.

${ }^{76}$ L. Collamore, nav. delo, str. 522-528, 544-546, 562-564 in 570.

${ }^{77}$ Michel Huglo, Grundlagen und Ansätze der mittelalterlichen Musiktheorie von der Spätantike bis zur Ottonischen Zeit, Geschichte der Musiktheorie IV, Die Lehre vom einstimmigen liturgischen Gesang, ur. Thomas Ertelt in Frieder Zaminer, Darmstadt, Wissenscahftliche Buchgesellschaft, 2000, str. 17-102: 97.

${ }^{78}$ Prim. L. Collamore, nav. delo, str. 241, sl. 6.2.

${ }^{79}$ Rokopis 273 ima na fol. 29v prav tako to antifono, ki jo pripisuje 5. modusu; gl. sliko 1. Zaključek 
spremenjen, da bi ustrezal 8. modusu namesto $5 .{ }^{80} \mathrm{~V}$ večini rokopisov je ob psalmu te antifone zapisana tudi diferenca in mnogi navajajo diferenco 5. tona, čeprav se antifona v njih konča na g. Dva rokopisa navajata tudi intonacijo, in obakrat je to intonacija F; ustrezna diferenca pripada $\mathrm{v}$ teh dveh rokopisih 5. tonu, čeprav se v enem (S9) antifona konča na $g$ in sodi torej v 8. modus. Rokopis MB ima intonacijo in diferenco 8. tona.

Zanimive so tudi tiste fraze spevov v 8. modusu, ki se v nekaterih rokopisih začenjajo na f, v drugih na g. ${ }^{81}$ Pripisovanje 5. ali 8. modusu pa ni edini primer različnega modalnega tolmačenja spevov. Nekateri rokopisi (akvitanski, severnofrancoski, italijanski) označujejo moduse spevov s številkami, in v primerih, ko so ob oznakah modusa še diference psalmov, se te ne ujemajo zmeraj s številkami modusov. ${ }^{82}$

$\mathrm{V}$ akvitanskih rokopisih je toliko takih primerov, da jih ni mogoče razlagati kot napake ali naključja. Nekateri primeri intonacije F v psalmodiji 8. tona so povezani $\mathrm{z}$ ambivalentnostjo spevov, ki se včasih pripisujejo 5. modusu, včasih pa 8. modusu. Zdi pa se, da je vsaj rokopis S9, ki intonacije redno navaja, glede 8. modusa konsistenten, saj uporablja v vseh navedenih primerih za 8. ton intonacijo F. Za večino akvitanskih rokopisov sicer ne moremo vedeti, katero intonacijo so predvidevali za 8 . psalmov ton, saj intonacij ne navajajo, ni pa izključeno, da je bila to intonacija F.

Še nekoliko širši vpogled v problematiko intonacije F bi omogočili drugi akvitanski rokopisi, morda akvitanski tonarji. O njih je največ razpravljal M. Huglo, vendar so bile njegove raziskave usmerjene predvsem $\mathrm{v}$ razvrščanje tonarjev $\mathrm{v}$ posamezne skupine, $\mathrm{v}$ ugotavljanje njihovega izvora in njihovih medsebojnih povezav, manj pa se je ukvarjal z njihovo podrobno vsebino. ${ }^{83}$ Poleg tega imajo mnogi akvitanski tonarji vrzeli, in zdi se, da v njih manjkajo največkrat ravno navedbe za zadnje moduse.$^{84}$ Vendar Huglo opozarja, da navajajo nekateri rokopisi za iste speve različne psalmove tone. Tudi iz tonarjev je torej razvidno, da praksa znotraj ene tradicije ni bila enotna. ${ }^{85}$

Gradual iz Narbonne, ${ }^{86} \mathrm{ki}$ je nastal med 11. in 13. stoletjem, ima na koncu rokopisa, med foliji 122v in 130v, priključen kompleten akvitanski tonar, kjer je na fol. 129v zapisan tudi 8. ton oficijske psalmodije. Iz dostopnega faksimila ni razvidno, ali sta na ustreznem mestu napisani dve različni noti, g in $\mathrm{f}$, ali pa samo nota na $\mathrm{f}$, in je tisto, kar se zdi ton g, le nehotni madež. Ton g, s katerim se zaključi verz (diferenca), je vsekakor napisan višje kot začetni ton doksologije Gloria patri. Gotovo pa je intonacija F zapisana v nadaljevanju, pri drugem verzu. Narbonnski tonar je tako še en primer, ki potrjuje, da je bila intonacija

ima isto melodično različico kot večina akvitanskih rokopisov. Prim. L. Collamore, nav. delo, str. 264.

${ }^{80}$ Mdina B in P9. L. Collamore, nav. delo, str. 273.

${ }^{81}$ L. Collamore, nav. delo, str. 269.

${ }^{82}$ L. Collamore, nav. delo, str. 356.

${ }^{83}$ M. Huglo, Tonaires, str. 129-165.

${ }^{84}$ Prim. npr. M. Huglo, nav. delo, str. 138 in 140. Tu v rokopisu London, British Museum, Harleian 4951, manjkata 7. in 8. psalmov ton, v rokopisu Pariz, BN lat. 776, pa manjkajo zadnji trije toni (6.-8.).

${ }^{85}$ M. Huglo, nav. delo, str. 146.

${ }^{86}$ Pariz, Bibliothèque nationale, lat. 780. Rokopis je v digitalni obliki dostopen na spletnih straneh Narodne knjižnice v Parizu, Bibliothèque numérique, http://gallica.bnf.fr (11. november 2011). 
F znana tudi v akvitanski tradiciji. Vendar bi bila za ugotavljanje tega, kako pogosta je, kje in kdaj se $\mathrm{v}$ akvitanskih virih pojavlja, potrebna mnogo obširnejša raziskava, ki bi vključevala veliko število raznovrstnih akvitanskih virov.

$\mathrm{V}$ zaključku te razprave lahko ugotovimo, da sodi intonacija F, prisotna $\mathrm{v}$ dveh kartuzijanskih antifonarjih iz 13. stoletja, med temeljne značilnosti ene od skupin kartuzijanskih rokopisov med 12. in 14. stoletjem. Razumemo jo lahko kot eno od razlikovalnih podrobnosti v navidez shematični enotnosti kartuzijanskih antifonarjev. Pregled vseh ohranjenih kartuzijanskih antifonarjev 13. in 14. stoletja, če že ne vseh ustreznih kartuzijanskih glasbenih rokopisov tega obdobja, bi nedvomno razkril nove povezave in sorodnosti med kartuzijanskimi rokopisi in tako prispeval k izostritvi slike kartuzijanskega glasbenega življenja v srednjeveški Evropi.

Razprava je pokazala, da ima kartuzijanska intonacija F svoj možni izvor v akvitanski tradiciji, ki je intonacijo $\mathrm{F}$ nedvomno poznala. Vprašanje izvora in razširjenosti te intonacije bi bilo možno nadalje preučevati z upoštevanjem vseh liturgičnih tradicij, ki so bile povezane s kartuzijanskim redom v začetku njegovega delovanja. Takšna raziskava bi omogočila trdnejšo domnevo o tem, od kod so kartuzijani prevzeli intonacijo $\mathrm{F}$, obenem pa bi bila prispevek k poznavanju povezav med srednjeveškimi glasbenimi rokopisi. 


\section{VARIANT EIGHTH-PSALM TONE INTONATION \\ IN THE CARTHUSIAN LITURGICAL TRADITION}

\section{Summary}

A special intonation of the 8th psalm tone, cosisting of the notes Fa, La and Do (the socalled Fa-intonation), was found in two 13th-century Carthusian antiphoners. Further comprehensive research has shown that this intonation was characteristic for a large group of Carthusian music manuscripts, written between the 12th and the 14th centuries. It was possible to find the Fa-intonation in different kinds of the Carthusian music manuscripts of that period: next to other antiphoners, there were also graduals and tonaries. But in the 15 th-century manuscripts the Fa-intonation was already very rare. Another (and more generally known) intonation of the 8th psalm tone seems to have become standardized for all Carthusian manuscripts in as late as the 14th century: this was the so-called Solintonation (consisting of the notes Sol, La and Do). However, for a certain period the Fa-intonation was one of the significant distinguishing details in the seemingly cosistent tradition of Carthusian antiphoners. A general survey of all extant Carthusian antiphoners from the 13th and 14th centuries would most likely shed new light on the connections and affinities between the Carthusian manuscripts, and in this way an image of Carthusian musical life in medieval Europe could become clearer.

The following comparisons have shown that a probable source for this Carthusian 8th psalm tone intonation could be found in the Aquitanian tradition. Some Aquitanian manuscripts knew the Fa-intonation, although the psalm tone intonations are missing in most of the sources. Furthermore, questions about the sources for this intonation and its use could also be researched in the connection with other liturgical traditions which have influenced the Carthusian liturgy during the period of the orders's foundation. Such research would make it possible to establish firmer hypotheses about the origins of the Carthusian variant 8 th psalm tone intonation, and thus make a contribution to closer knowledge about the connections between medieval music manuscripts. 